\title{
Measurement the Performance Levels of Islamic Banks in Jordan
}

\author{
Yazan Radwan Qasim, Norhazlina Ibrahim, Safeza Bt Mohd Sapian, Murad Ali Al-Zaqeba \\ Faculty of Economics and Muamalat \\ Universiti Sains Islam Malaysia 71800 NilaiNegeri Sembilan, Malaysia \\ E-mail: wolf_mgableh@yahoo.com
}

Received: June 27, 2017 Accepted: July 20, 2017 Online published: August 7, 2017

doi:10.5296/jpag.v7i3.11451ＵRL: https://doi.org/10.5296/jpag.v7i3.11451

\begin{abstract}
For now, there are incomplete studies to investigate the Jordan Islamic banks' (IBs) performance. Also, there is evidence of increasing withdrawal of investors from IBs to commercial banks as a result of decreased confidence among depositors and minimize of profits. This study focuses on using secondary data analysis to measure the performance of three IBs in Jordan over the period of 2005-2015. The Jordanian IBs are as follow; Jordan Islamic Bank for Finance and Investment (JIBFI), Islamic International Arabic Bank (IIAB), and Jordan Dubai Islamic Bank (JDIB). The analytical part consists of two intervals; the first interval from (2005-2009) for JIBF and IIAB. The second interval from (2010-2015) includes the three IBs. This study will include three measuring tools; (1) Financial Ratio Analysis, (2) Data Envelopment Analysis and (3) Maqasid Index.
\end{abstract}

Keywords: FRA, DEA, MI, Performance, and IBs.

\section{Introduction}

Bank's performance is important for all parties; depositors, bank managers, regulators, and competitive market (Qasim et al., 2017). The bank performance provides a signal to investors-depositor whether to withdraw funds from investment or withdraw funds from the bank. It also helps to improve the banking services (loan or deposit), where at the same time it help to enhance the bank finance (Samad \& Hassan, 1999). There are two classes of banks; Islamic and conventional. The Conventional Banks get the profits by the spread between the interest that paid from borrowers and interest that paid to depositors (Santos, 2000). Islamic Banks operate a system that derived from the principles of Islamic Shariah law and governed by the concepts of Islamic economics. The salient features of Islamic banks differ from conventional banks as the former must pay zakat imposed on the proceeds after a year has 
passed. Due to the religious obligation of the banks, owners of this capital (shareholders and depositors) can authorize the bank on its behalf to dispose zakat through its legal channels as well as for charity and donations that might be decided by the crown command from additional spending for the benefit of the Muslim community and to achieve social solidarity (Al-Talib, 2005).

Banks Performance is a broad concept and can be understood from different viewpoints of researchers. It can be defined as the relationship between financial resources and the results from the management of these resources by the financial organization and its objectives of seeking to generate more profits by providing good products and services. On the other hand, performance reflects the style of the unity and the financial situation of funds and investment (Assi, 2010). Nameh \& Hussein (2002) clarified that performance is the outcome of an institution's financial operations. Apart from that, Jones \& George (2010) stated that performance evaluation provides feedback and guidance to an organization in the development of strategies which will improve the organization. It is also a measure of how well the bank can utilize its assets via various currently available modes of generating revenues or business. In addition, one can utilize performance as a basis for comparison between the banks' services (Ajlouni \& Moh'd, 2011). Qasim et al. (2017) stated there are differences of viewpoints of the researcher, it can be concluded that the measure of financial performance consists of revenues, costs, and profits. An institution that is considered to be having a good performance is described as one that generates the highest value of revenues and pays lesser costs to achieve a higher percentage of profits. Recently, measurement of financial performance concerns in the Financial Institutions has attracted a lot of the researchers' attention given that structures and financial performance measurement are quickly changing. This shows that there has been a considerable interest in the measurement of performance with evolving institutions and analysis in the banks. It is important to evaluate a bank's performance by monitoring the financial condition overall, which is necessary for investors, depositors, regulators, and managers in banks (Ajlouni \& Hmedat, 2011). Indeed, the spread of the Islamic banking sector generated the need to estimate the financial performance, as Islamic banking sector impose its presence day after day in the banking arena. Table 1 explains the growth of Islamic banking within a ten-year period over the comparison with a commercial banking sector the duration every five years. 
Table 1. Assets of Islamic Banks as a Share of Total Bank Asset in MENA Nations.

\begin{tabular}{|c|c|c|c|c|c|}
\hline MENA Nations Banks & Assets & 1993 & 1998 & 2003 & Currency Millions \\
\hline \multirow{3}{*}{$\begin{array}{l}\text { Egyptian : } \\
\text { Faisal Islamic Bank }\end{array}$} & Bank Assets & 5460.7 & 6843.63 & 13946.49 & \multirow[t]{3}{*}{ Egyptian Pounds } \\
\hline & $\begin{array}{l}\text { Total } \\
\text { Assets }\end{array}$ & 198250 & 329562 & 577937 & \\
\hline & Bank Shares & $2.75 \%$ & $2.08 \%$ & $2.41 \%$ & \\
\hline \multirow[t]{3}{*}{ Saudi Islamic Bank } & Bank Assets & & & 16727.58 & \multirow[t]{3}{*}{ Egyptian Pounds } \\
\hline & $\begin{array}{l}\text { Total } \\
\text { Assets }\end{array}$ & & & 577937 & \\
\hline & Bank Shares & & & $2.89 \%$ & \\
\hline \multirow{3}{*}{$\begin{array}{l}\text { Jordanian: } \\
\text { Jordan Islamic Bank }\end{array}$} & Bank Assets & 528.26 & 706.67 & 1159.2 & \multirow[t]{3}{*}{ Jordan Dinars } \\
\hline & $\begin{array}{l}\text { Total } \\
\text { Assets }\end{array}$ & 6747.5 & 10460.3 & 15701.5 & \\
\hline & Bank Shares & $7.83 \%$ & $6.76 \%$ & $7.38 \%$ & \\
\hline \multirow{3}{*}{$\begin{array}{lll}\text { Islamic } & \text { International Arab } \\
\text { Bank } & & \end{array}$} & Bank Assets & & 843.96 & 1544.7 & \multirow[t]{3}{*}{ Jordan Dinars } \\
\hline & Total Assets & & 10460.3 & 15701.5 & \\
\hline & Bank Shares & & $8.07 \%$ & $9.84 \%$ & \\
\hline \multirow{3}{*}{$\begin{array}{l}\text { Saudi Arabia: } \\
\text { Al-Rajhi }\end{array}$} & Bank Assets & 28598.49 & 38055.45 & 64678.32 & \multirow[t]{3}{*}{ Saudi Riyals } \\
\hline & Total Assets & 320754 & 404306 & 545208 & \\
\hline & Bank Shares & $8.92 \%$ & $9.41 \%$ & 11.86 & \\
\hline \multirow{3}{*}{$\begin{array}{l}\text { Other: } \\
\text { Bank Al-Jazira }\end{array}$} & Bank Assets & & 42982.04 & 63667.01 & \multirow[t]{3}{*}{ Saudi Riyals } \\
\hline & $\begin{array}{l}\text { Total } \\
\text { Assets }\end{array}$ & & 404306 & 545208 & \\
\hline & Bank Shares & & $10.63 \%$ & $13.51 \%$ & \\
\hline \multirow{3}{*}{$\begin{array}{l}\text { Al-Kuwait: } \\
\text { Finance House }\end{array}$} & Bank Assets & 1156.01 & 1669.21 & 3041.11 & \multirow[t]{3}{*}{ Kuwait Dinars } \\
\hline & $\begin{array}{l}\text { Total } \\
\text { Assets }\end{array}$ & 9068.55 & 12965 & 18329.85 & \\
\hline & Bank Shares & $12.75 \%$ & $12.87 \%$ & $16.59 \%$ & \\
\hline \multirow{3}{*}{$\begin{array}{l}\text { Other: } \\
\text { Islamic-Investment Houses }\end{array}$} & Bank Assets & 1175.97 & 1794.66 & 4075.81 & \multirow[t]{3}{*}{ Kuwait Dinars } \\
\hline & $\begin{array}{l}\text { Total } \\
\text { Assets }\end{array}$ & 9068.55 & 12965 & 18329.85 & \\
\hline & Bank Shares & $12.97 \%$ & $13.84 \%$ & $22.24 \%$ & \\
\hline
\end{tabular}

Since the beginning of its inception, and despite the challenges and obstacles and strong competition from traditional banks in addition to the spread of Islamic banks and institutions, the growth rate has exceeded $15 \%$. This research aims to explore the various performance measurement methods of Jordanian Islamic banks which clarify the advantages and disadvantages of each measurement method. In this context, the formulation of useful measurement matrix of the performance levels of Jordanian Islamic banks could be proposed. 


\section{Related Works}

Based on the review of the literature, there are three main techniques were being used to measure the performance of Islamic banks. These techniques are the following;

\subsection{Financial Ratios Analysis}

FRA, which was first applied in the 1930s, is a tool for measuring a company's performance. Osteryoung et al. (1992) mentioned that financial ratios were vastly used by; financial analysts, lenders, small business managers, and academic researchers. In recent years, there are a lot of studies conducted to measure the performance of the banking sector by utilizing FRA as a methodology (Samad \& Bashir, 1999; Samad \& Hassan, 2000; Yudistira, 2003; Rim \& Stiroh, 2003; Al-Maghaireh, 2005; Moin, 2008; Shehzad \& Kamran, 2012; Omari, 2013; Hunjra \& Bashir, 2014; Olarewaju, 2015). Al-Maghaireh (2005) compared the performance between IBs and Non-IBs in the UAE using FRA. This study showed that the IBs are more competent than non-Islamic banks in terms of profitability, solvency, and liquidity and are deemed less risky in all types of over the period of 5 years from 2000 to 2004.

Recently, Hunjra et al. (2014) conducted a study in Pakistan to measure the financial performance of CBs and IBs in order to assist the bank shareholders, managers, depositors, regulators, and investors by providing true information on the financial position of the banks. Using the banks' annual financial statements from the years 2008-2012, the study applied FRA. Nineteen ratios were used to investigate their performances in terms of capital adequacy, profitability, risk and solvency, liquidity, operational, deployment and cash flow. The finding resolved that IBs are less profitable, deployed and operationally competent with more liquid and less risky investment in comparison to the CBs. There are significant mean differences in terms of the profitability, capital adequacy, and cash flow ratios between these banks.

Shehzad \& Kamran (2012) performed a study conducted in Pakistan with the intention of making the comparison between the financial performances of the Islamic banking sector and Conventional Banking sector from the year 2007-2011. To present a vivid picture of IBs to the stakeholders, the authors clearly stated that the financial analysis obtained from the IBs were not as thorough as those from the well-established CBs in Pakistan. To investigate the performance, six Financial Ratios Analysis (FRA) were found useful in testing the performance of eight 8 sampled banks. The finding showed that IBs poses less risk and are less competent in Expense Management (EM) when compared to CBs. No significant difference observed for productivity for both banking fields and the IBs performance was found satisfactory.

According to Najjar (2013), an investigation of the financial performance of Al-Bahrain banks covered the estimation of essential financial ratios of major financial institutions and a comparison was made with regard to its performance in the context of the worldwide crisis in 2008. The study presented financial ratios comparison between the CBs and Islamic financial institutions. These ratios described the financial performance, profitability, type of banks and 
size. It revealed that financial management practices of banks are changing in their individual areas. Findings also showed the existence of broad divergence in the financial ratios utilized and their values obtained by IBs and CBs prior to and after the financial crisis, as well as it helped to clarify the finest practice in the areas of the liquidity management, profitability management, interest rate and risk management. The finding revealed the existence of corporate excellence in the valuation of equity shares and asset management IBs. Besides that, the analysis is being used as a foundation for preventive actions in the future to provide early warning signal for bankruptcy, and escalating market risk.

Furthermore, the study conducted by Hamouri \& Radaydeh (2014) in Jordan revealed the effects of conventional financing and Islamic financing on the performance of Jordanian industrial establishments over the years 2001-2010 using the financial ratios. The study utilized T-test and F-test to verify hypothesis whether there were statistically positive variances between the financing types utilized by industrial companies and their effects on performance. The findings showed that the companies that apply the Islamic financial system have attained obvious benefits in the majority of the financial ratio utilized. However, the statistically significant variances are negative between industrial companies that follow the Islamic financial system and the industrial company that follows conventional funding system for most of the financial ratios except for the rate profit-expenses and the rate income-expenses. The study also revealed a statistically significant positive variance at the level of borrowing rate of equity, the efficiency of operations index and the asset utilization rate.

Samad (2004) conducted a study to explain the performance and make comparisons between six of Islamic banks with fifteen commercial banks in Bahrain by using three ratios to gauge their profitability, liquidity risk, and credit risk starting from 1991 to 2001. It was revealed that there are no differences in terms of the profitability and liquidity of these banks. In terms of size and their performances, CBs are more superior to IBs. Conversely, the CBs are more exposed to credit risk than IBs, with IBs' credit performances far exceeding the CBs.

Likewise, Samad \& Hassan (2000) evaluated the inter-temporal and inter-bank performance between Bank Islam Malaysia Berhad (BIMB) and eight CBs in terms of their profitability, liquidity, and solvency risks on the community involvement. From1984 to 1997, they applied the financial ratio analysis to estimate the performance of BIMB via T-test and F-test to determine the significance of the results. This study discovered that BIMB shows relatively higher performance as it is more liquid and less risky at a particular period of time. Besides that, Islamic bank (IB) showed a statistically significant positive result on both the ROA and ROE over the study period. It was also found that BIMB risk increases significantly after checking by equity multiplier and debt to equity ratio. Nonetheless, the comparison indicates that Islamic bank is more solvent and still less risky.

\subsection{Data Envelopment Analyses}

DEA is originally developed by Farrell (1957) to investigate the efficiency in the firms. Charnes et al. (1978) developed DEA for examining the efficiency of public sector organizations. Sherman \& Gold (1985) began are the first to apply DEA in the banking 
sector). Recently, there are many of studies conducted to measure the performance of the banking sector by using DEA (Halkos and Salamouris, 2004; Havrylchyk, 2006; Said, 2011; Shah \& Ahmed, 2012; Omari, 2013; Tahir et al, 2013; Eriki \& Osifo, 2015).

Again, the change in efficiency and the change in Total Factor Productivity (TFP) are negatively related to the banks' age. A study by Kazaj \& Sadeqi (2003) examined the ability of IBs in financing business operations all over the world during the years 2000-2001, by using DEA. They recognized the efficient score was among 41-46 for Islamic banks. The study used analytical model despite the short study period. However, some literature argues that efficiency is considered a leading factor in the country where the Islamic Banks are in operation.

Yudistira (2003) gave fresh evidence on the performance of the eighteen Islamic banks in the MENA region from 1997-2000. The efficiency alternative across the sample appears to be influenced mainly by country-specific factors. Another study attempted to compare cost control and the efficiency of profit generation. Kamaruddin et al. (2008) investigated this subject in fully-fledged IBs with Islamic window transaction of domestic and foreign banks in Malaysia from1998-2004 by using DEA. He opined that IBs are relatively more competent at controlling costs than at yielding profits as the major contributor to cost efficiency of foreign and domestic banks is resource management and the economic situation at that point in time.

Furthermore, Johns, Izzeldin \& Pappas (2009) accomplished their research by comparing the performance of interest based and non-interest based banks using the DEA after and during the crisis from 2004-2009. Non-Islamic banks and IBs showed an insignificant dissimilarity in mean when efficiency is measured against the common frontier. However, the study presented a few basic changes of using the Meta Frontier Analysis (MFA) between the IBs and CBs. The IBs efficiency frontier lies inside the frontier for CB. The location reveals that the IBs' systems are less competent during the financial crisis in comparison to CBs. Johnes, Izzeldin \& Pappas (2012); Majid (2005) and Bhattacharyya et al. (2010) found a reasonable amount of reasons for a comparatively weaker performance of IBs than that of the non-Islamic banks (N-IB). Firstly, stringent Shariah rules and restrictions limit the issuance of non-standardized, which consequently, raises IBs' operational cost in comparison to N-IB. Secondly, the size of IBs is generally smaller compared to that of N-IBs, with IBs portraying an increased technical efficiency (Majid et al. 2005; Bhattacharyya et al., 2010).

A review the analysis of Islamic banks' efficiency using both the alternative approach and standard approach found that the incompetence level among Islamic banks using the Standard Data Envelopment Approach (S-DEA) is greater than using the Alternative Data Envelopment Approach (ADEA) (Tahir et al., 2013).

Maredza et al. (2013) measured the changes in the efficiency and productivity from the period of 2000-2010 by using the DEA methodology. He argued that productivity is the main factor that causes $17 \%$ drop in efficiency during crisis compared to the period prior to the crisis. 


\section{Mll Macrothink}

Journal of Public Administration and Governance

ISSN 2161-7104

2017, Vol. 7, No. 3

There was another study conducted on Islamic banks in Jordan to measure the performance efficiency analysis. Based on the limited studies on Islamic banks', this research garnered much attention with its analysis of performance efficiencies of Jordan Islamic banks. It focused on the two largest Islamic banks in Jordan in the areas of performance evaluation and profit maximization using two sophisticated techniques, which are panel data regression models and data envelopment analysis (DEA) to compare the performance of Jordanian IBs with CBs (Saleh \& Zeitun, 2004).

A study conducted by Omari (2013) revealed the measurement of effective performance in Jordanian Islamic banks using both methods of DEA and FRA from 2005-2009. The aim of the study was to measure and compare the development of relative performance efficiency conducted with three Islamic banks in Jordan, one of which was excluded from this study because it was recently established. This study found that the Islamic banks are steady and efficient in terms of their inputs in producing actual outputs. For more reliable and sustainable results, the researcher should consider extending the time period of the study longer than 2 years.

A study by Eriki, \& Osifo (2015) in the United Kingdom to compare between the commercial banks and Islamic banks in Nigeria with regard to their performance efficiency in the industry using three of the measurement efficiency performance has revealed that age and size of a bank related positively to performance. The researcher also recommended that strong and efficient resources management and risk management policies are put in place by the banks' management.

Finally, Abduh, Hasan \& Pananjung (2013) measured the efficiency among five IBs in Bangladesh. The data was gathered from annual published reports from 2006 to 2010. Researchers used ratio analysis to measure the performance efficiency using DEA with Malmquist Index and FRA. The findings revealed that Shajalal IB has performed better than other IBs in terms of the financial ratios investigated. The finding of DEA revealed that positive trend of all IBs over the period of 2006-2010 suggesting that Islamic banks have improved their efficiency over the study period as can be seen from the above review and previous studies seeking to investigate the performance of IBs in comparison with the commercial banks, using either of FRA or DEA. A few of the literature have compared the findings of these two techniques simultaneously. However, this study is seeking to fill the gap and employ both of these two methodologies to measure the performance efficiency in Jordanian Islamic banks, using DEA and FRA.

\subsection{Maqasid Index}

Limited studies have evaluated the performance of Islamic banks using Maqasid Index. Mohammed, Dzuljastri \& Taib (2008) in their study have utilized the performance measures in the Islamic banking sector based on the Maqasid framework. While the Maqasid index concepts were developed by using Simple Additive the Weighting (SAW) method. The study used six samples of Islamic banks, namely, Islamic Bank Bangladesh (IBB), Bank Muamalat Malaysia Berhad (BMMB), BSM Indonesia, Sudanese Islamic Bank (SIB), Bahrain Islamic Bank (BIB), and Islamic International Arab Bank-Jordan (IIABJ) in the span of five years 
from 2000 to 2005 .

The variables used referred to Abu Zahrah and the theory of Maqasid Shariah that are covered by Tahdzib Al-fared, Iqamah Al-Adel, and Maslahah. Those variables can be operated by using Sekaran's concept that generated ten ratios as the performance indicators. The results showed that no single bank can be regarded as having high performance via those ratios. Nevertheless, IIABJ acquires the highest grade followed by BSM Indonesia, BIB, IBB and BMMB and lastly, SIB. Nevertheless, the IBs must revalue their aims and objectives that conform to Maqasid Shariah (Mohammed, Dzuljastri \& Taib, 2008).

Apart from that, Mughess in his study entitled "A recent financial advance of IBs and their fulfilment of Maqasid Shariah" has identified the gap in the illustration of the performance growth and the analysis in banks such as; Meezan Bank (Pakistan), Bank Islam Malaysia Berhad (BIMB) and UAE bank on the condition of a financial growth with Maqasid Shariah. By using the simple additive weighting (SAW) method with a grid, the matrix revealed that the combined rating result of the three Islamic banks with the grid matrix showed the increased advancement of Islamic banking from the financial side, however, there is a lack of achievement on Maqasid Shariah (Mughess, 2008).

Meezan Bank (Pakistan) has obtained an A- rating, which means that there is a high growth in both its financial performance and achievement of the Maqasid Shariah, United Arab Emirates bank has B- rating which means declined growth in financial performance but it has accomplished a high achievement of Maqasid Shariah. Bank Islam Malaysia Berhad (BIMB) has produced quick growth of financial performance, but there is a decrease in the accomplishment of the Maqasid-index (Mughess, 2008).

A study was conducted by Syafii et al. (2012) in order to analyze the performance in the Islamic banking industry between Jordan and Indonesia, using a Maqasid index that found that BMI in Indonesia achieved a total ratio of MI of 17.839\%. It means that BMI displays better performance than the other three IBs according to MI approach, followed by BSM with $16.19 \%$ (1\% difference). IIAB and JIB obtain the ratio of $10.295 \%$, and $8.152 \%$ respectively. Hence, it is safe to say that some of the IBs are unable to represent the great value of the MI.

\subsection{Summary of Related Works}

Financial ratio analysis technique is utilized to measure and investigate the performance efficiency of Islamic banks. FRA is useful for determining the financial situations of Islamic banks. In relation to the DEA technique, it appears that fewer advances have been made to the FRA technique since its first utilization in 1984 to measure performance. DEA is also utilized to control costs and generate more profits. Besides that, Maqasid shariah's index is utilized to choose a solution from alternatives candidates that lead to an improvement in decision making. It is a new analytical tool that will be adapted to investigate performance efficiency of Jordanian Islamic banks.

Finally, limited researches were conducted on Jordanian Islamic banks, this research tries to examine the financial performance for a long period that starting from 2005 to 2015. Most of the Jordanian researchers avoided studying the Islamic banks, as the previous studies show a 
few studies on Islamic banks conducted in Jordan.

\section{Discussion of Related Works}

Based on the reviewed works in the above section, FRA technique utilized to measure and investigates the performance efficiency of Jordanian Islamic banks. We need to use FRA for determining the financial situations of Islamic banks. In relation to the DEA technique, it appears fewer advances have been made to the FRA technique. Also, DEA utilized to control costs and generating more profits. However, it can be observed that Maqasid shariah's index is to choose a solution from alternatives candidates that lead to an improvement in decision making. It is a new analytical tool that will be adapted to investigate performance efficiency of Jordanian Islamic banks.

Table 2. Summarizes the main utilizing purpose of each performance measurement methods in Jordanian Islamic banks.

\begin{tabular}{|c|c|c|}
\hline $\begin{array}{l}\text { Measurement } \\
\text { Method }\end{array}$ & Utilizing Purpose & Source \\
\hline FRA & $\begin{array}{l}\text { Easy to calculate, interpret, and can examine efficiency from } \\
\text { the variations perspectives including; revenues, costs, and } \\
\text { profits. Also, it reflects the relative average of growth both of } \\
\text { tangible wealth and financial assets FRA utilizes to be more } \\
\text { extremely accurate in predicting the bankruptcy of firms. }\end{array}$ & $\begin{array}{l}\text { (Johnes \& } \\
\text { et al., } \\
\text { 2009). } \\
\text { (Beaver, } \\
\text { 1966). }\end{array}$ \\
\hline DEA & $\begin{array}{l}\text { It's utilized to control costs the inputs-outputs for generating } \\
\text { more profits. } \\
\text { It's will use to analyses the scale efficiencies and technical of } \\
\text { Jordanian Islamic banks by specifying (input-output) } \\
\text { variables of IBs. }\end{array}$ & $\begin{array}{l}\text { (Omari, } \\
\text { 2013) }\end{array}$ \\
\hline MI & $\begin{array}{l}\text { To choose a solution from alternatives candidates that lead to } \\
\text { an improvement in decision-making and generating more } \\
\text { profits. }\end{array}$ & $\begin{array}{l}\text { (Antonio \& } \\
\text { et al., } \\
2012)\end{array}$ \\
\hline
\end{tabular}

From above table, It can be noticed that each performance measurement method can be for a specific purpose, and each method has its own advantages over other methods which represent the importance of each method for banks performance measuring. Alomari (2011) tried to enhance the performance measurement accuracy of Jordanian Islamic Banks through measure the performance using two mixed methods; FRA and DEA. The analyses between these two methods support the performance measurement based on two bases which are profits and costs.

There is a limitation in the works of performance measurement using mixed methods for Jordanian Islamic banks. Deeply, there is a limitation in the analyses among three measurement methods (FRA, DEA, and MI). This analyse is recommended in the next section to enhance the accuracy of performance measurement. 


\section{Macrothink}

\section{Recommendation}

Based on the limitation in the studies of analyses between the three measurement methods (FRA, DEA, and MI) for Jordanian Islamic bank, this research recommended the analyses between various measurement methods in order to enhance the accuracy of performance measurements of banks. FRA can be utilized to determine the financial performance situations of Jordanian Islamic banks "profitability". DEA can be utilized to improve Islamic banking industry "costs" in Jordan. MI can be utilized examine the performance efficiency of Jordanian Islamic banks "Islamic law". Therefore, FRA, DEA, and MI (Figure 1) could be utilized to measure the profitability, costs, and efficiency of Islamic banks, which provide accurate performance measurement more than each individual measurement method and determined the future risks.

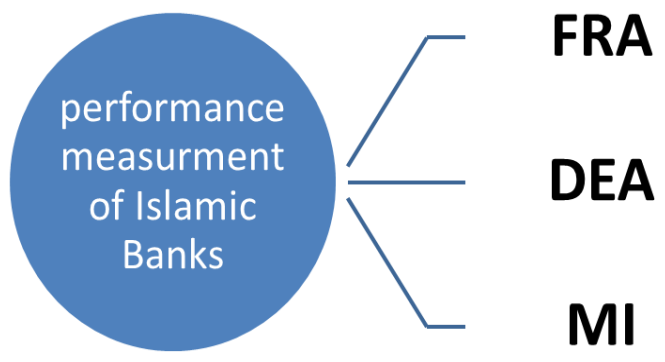

Figure 1

The following procedures are proposed to conduct the analyses between various performance measurement methods:

1. Compute FRA from the annual reports of Jordanian Islamic banks, and rank the banks' performance according to means of FRA.

2. Compute the DEA performance of Jordanian Islamic banks, and rank the banks' performance according to the efficiency scores of DEA.

3. Calculate MI performance of Jordanian Islamic banks, and rank the banks' performance according to the MI.

4. Rank the performance of Jordanian Islamic banks based on the methods:

a. The financial ratios analyses (FRA) will rank based on the mean of FRA with clarifying the nature of the relationship between performance and ratios (Qasim et al., 2017).

b. The data envelopment analyses will rank based on the efficiency score.

c. The Maqasid Index (MI) will rank depends on Maqasid Index model equation.

d. Calculating the total rank for these methods and comparison among three banks to choose the preferable bank for investment. 


\section{Conclusion and Future Works}

The performance measurement of Jordanian Islamic banks is important to understand the financial situation of these banks such as profitability, costs, and efficiency. There are several measurement methods can be utilized to measure the performance of Islamic banks; FRA, DEA, and MI. Each method is effective for specific measurement purpose. There is a limitation in the works that integrate between the three measurements methods to measure the performance of Jordanian Islamic banks. This study recommended the combination among FRA, DEA, and MI in order to enhance the accuracy of performance measurement of Jordanian Islamic banks. In the future, the recommended combination could be conducted and test based on real data collected from annual reports of Islamic Banks in Jordan. Also, the researcher recommended each method should take coefficient importance comparing with other methods. Thus, the rank of each method will be multiplied by its importance coefficient before computing the final performance ranking of each bank depends on the three measurement ranks.

\section{References}

Ajlonui \& hmedat. (2011). The relative efficiency of Jordanian banks and its determinants using data envelopment analysis. Journal of Applied Finance \& Banking. 34-58.

Al-Maghaireh, A. (2005). Comparative Financial Performance of Islamic Banks vis-à-vis Conventional Banks in the UAE. Working Paper Dept of Economics and Finance. UAE University: Al-Ain. p. 22-35.

Al-Talib, G, S. (2005). Assessing the financial performance of the Islamic Bank. Dar Al-salamm. Dar Al-Salaam for printing and publishing. 12-23.

Antonio, Mohd S., Sanrego, Y., \& Taufiq, M. (2012). An Analysis of Islamic Banking Performance: Maqashid Index Implementation In Indonesia and Jordan. Journal of Islamic Finance, 1(1), 012-029.

Assi Amarh Mohammed Yahya. (2010). Assess the financial performance of Islamic banks: An Empirical Study on the Jordan Islamic Bank for Finance and Investment.

Mktatbat alkhatib, 1-135.

Beaver, W. H. (1966). Financial Ratios as Predictors of Failure. Empirical Research in Accounting Selected Studies, 1966 (Institute of Professional Accounting, January, 1967), pp. 71-111. Also a recent attempt was made to weight ratios arbitrarily, see M. Tamari, Financial Ratios as a Means of Forecasting Bankruptcy, Management International Review, Vol. 4, pp. 15-21. https://doi.org/10.2307/2490171

Charnes, A., Cooper, W. W., \& Rhodes, E. (1978). Measuring the efficiency of decision making units, European. Journal of Operational Research, 2(4), 429-444. https://doi.org/10.1016/0377-2217(78)90138-8

Hameed, Shahul et al. (2004). Alternative Disclosure and Performance Measures for Islamic Banks. Malasyia: IIUM. Ibnu 'Asyur, Muhammad Thahir. 2000. Maqashid Asy-Syariah 
Al-Islamiyyah. jordania: Darun Nafais. International Islamic Arab Bank. Annual Report tahun 2008-2010. Yordania. Accessed March 22, 2012. http:// IIABJank.com.jo.

Hisham Yahya, M., Muhammad, J., \& Razak Abdul Hadi, A. (2012). A comparative study on the level of efficiency between Islamic and conventional banking systems in Malaysia. International journal of Islamic and Middle Eastern finance and management, 5(1), 48-62. https://doi.org/10.1108/17538391211216820

Hunjra, A. I., \& Bashir, A. (2014). Comparative Financial Performance Analysis of Conventional and Islamic Banks in Pakistan. Bulletin of Business and Economics (BBE), 3(4). 196-206.

Ibrahim, M. (2015). Measuring the Financial Performance of Islamic Banks. Journal of Applied Finance and Banking, 5(3), 93-104.

Johnes, J., Izzeldin, M., \& Pappas, V. (2009). Efficiency in Islamic and conventional banks: A comparison based on financial ratios and data envelopment analysis. Economics Working Paper Series, The Economics Department, Lancaster University.

Kamaruddin, B. H., Safa, M. S., \& Mohd, R. (2008). Assessing Production Efficiency of Islamic and Conventional Bank Islamic Windows in Malaysia. International Journal of Business and Management Science, 1, 31-48.

Kuppusamy, Mudiarasan, Saleha, Ali Salman dan Samudhram, Ananda. (2010). Measurement of Islamic Banks Performance Using a Shariah Conformity and Profitablity Model. Journal Review of Islamic Economics, 13(2), 35-48.

Mohamed, M. O., Razak, D., \& Md Taib, F. (2008). The Performance Measures of Islamic Banking Based on the Maqasid Framework.

Mohammed, Dzuljastri dan Taib. (2008). The Performance Measures of Islamic Banking Based on the Maqashid Framework. Paper of IIUM International Accounting Conference (INTAC IV) held at Putra Jaya Marriott.

Mohammed, Mustafa Omar dan Taib, Fauziah Md. (2009). Testing the Performance Meaasured Based on Maqashid al-Shariah (PMMS) Model on 24 selected Islamic and Conventional Banks. Malasyia: IIUM.

Moin, M. S. (2008). Performance of Islamic banking and conventional banking in Pakistan: a comparative study.

Mughess, S. (2008). The Recent Financial Growth of Islamic Banks and Their Fulfilment of Maqashid al-Shariah Gap Analysis.

Olarewaju, O. M., \& Obalade, A. A. (2015). Evaluation of the determinants of operational efficiency in Nigerian deposit money banks. International Journal of Economics, Commerce and Management, 1-13.

Omari, H. O. (2011). Measuring Islamic Banks' Efficiency Using Data Envelopment Analysis (DEA) and Financial Ratio Analysis (FRA): The Case of Jordanian Islamic Banks during the 
Period 2005-2009 (Doctoral dissertation, Yarmouk University).

OSifo, O., \& Eriki, P. O. (2015). Determinants of performance efficiency in Nigerian banking industry: A DEA approach. International Journal of Economics, Commerce and Management, 3(2), 1-13.

Osteryoung, J., Constand, R. L., \& Nast, D. (1992). Financial ratios in large public and small private firms. Journal of Small Business Management, 30(3), 152-163.

Qasim, Y. R., Mohamad, Y., \& Ibrahim, N. (2017). Measuring the Performance of Jordanian Islamic Banks. Journal of Public Administration and Governance, 7(1), 25-47. https://doi.org/10.5296/jpag.v7i1.10575

Rime, B, \& Stiroh, K. (2003). The performance of universal banks: evidence from Switzerland bank finance, 27(2), 121-2150.

Said, R. M., \& Tumin, M. H. (2011). Performance and financial ratios of commercial banks in Malaysia and China. International Review of Business Research papers, 7(2), 157-169.

Samad, A., \& Hassan, M. K. (2000). The performance of Malaysia islamic banks during 1984-1997. An explanatory study. Thoughts on economics, 10(1-2), 1-25.

Samad, A., \& Hassan, M. (1999). The performance of Malaysian Islamic bank during 1984-1997: An exploratory study. International Journal of Islamic Financial Services, 1(3), $1-14$.

Santos, J. A. C. (2000). Bank Capital Regulation in Contemporary Banking Theory: A Review of the Literature. BIS working papers, No. 90, Bank for International Settlements: Monetary and Economic Department. Basel. Switzerland.

Shehzad, F., Sehrish, S., Saleem, F., Yasir, M., \& Ahmed, K. (2012). Financial performance analysis of Islamic banks and conventional banks in Pakistan.

Sherman, H. D. \& Gold, F. (1985). Bank branchoperating efficiency: evaluation with Data envelopment analysis. Journal of Bankingand Finance, 9, 297-315. https://doi.org/10.1016/0378-4266(85)90025-1

Tahir, I. M., Razali, A. R., \& Haron, S. (2013). Analysing Islamic Bank Efficiency in Malaysia Using the Standard and Alternative Approaches to Data Envelopment Analysis. Journal of Economics and Behavioral Studies, 5(11), 798.

\section{Copyright Disclaimer}

Copyright for this article is retained by the author(s), with first publication rights granted to the journal.

This is an open-access article distributed under the terms and conditions of the Creative Commons Attribution license (http://creativecommons.org/licenses/by/4.0/). 